\title{
Covid-19 Pandemic: Educational Transformation at Paramount Elementary School Palembang
}

\author{
Happy Fitria', Ali Maksum², Muhammad Kristiawan3 \\ DOI: 10.35445/alishlah.v13i2. 647
}

\section{Article Info \\ Keywords: \\ Pandemic; \\ Education; \\ Transformation \\ Technology}

Keywords:

Pandemi;

Pendidikan;

Transformasi

Teknologi

\section{Abstract}

With the increasing limited face-to-face learning methods due to the Covid-19 pandemic, there is a transformation process carried out in the education system. One of them is changing the new landscape of the education system at the primary, secondary, and higher education levels. The digital transformation of teachers and students is the impact of the learning process during the Covid-19 pandemic. This study is qualitative research that aims to determine how learning during the Covid-19 pandemic for one year at Paramount Palembang school was. The study results illustrate that the impact of the pandemic has caused adverse effects in the world of education due to the shift from conventional methods to online methods. However, the impact of this change is not always negative. Without realizing it, education has undergone a monumental transformation that forces all parties to change and be aware of the importance of technology in life, especially in education. The journey of transformation in each region as a result of the Covid-19 pandemic is undoubtedly different. The study results show that the journey of education transformation during the one-year Covid-19 pandemic at Paramount Palembang schools shows that all teachers enjoy this change and feel the benefits. The results of this study are significant to become the basis for the transformation of the education system in schools and education in general. The following policy is how all students can enjoy education transformation by integrating learning methods into online and offline learning.

\begin{abstract}
Dengan semakin terbatasnya metode belajar tatap muka akibat pandemi Covid-19, ada proses transformasi yang dilakukan pada sistem pendidikan. Salah satunya adalah mengubah wajah baru sistem pendidikan baik pada tingkat dasar, menengah maupun pendidikan tinggi. Transformasi digital guru dan peserta didik merupakan dampak dari proses pembelajaran selama pandemi Covid-19. Penelitian ini adalah penelitian kualitatif yang bertujuan untuk mengetahui bagaimana keadaan pembelajaran sepanjang pandemi Covid-19 selama satu tahun di sekolah Paramount Palembang. Hasil penelitian menggambarkan bahwa dampak pandemi telah menimbulkan efek negatif di dunia pendidikan karena beralihnya metode konvensional ke metode daring namun dampak perubahan ini tidak selamanya negatif. Tanpa disadari pendidikan telah mengalami transformasi secara monumental yang memaksa semua pihak berubah dan sadar akan pentingnya teknologi dalam
\end{abstract}

\footnotetext{
${ }^{1}$ Universitas PGRI Palembang, Indonesia

E-mail: happyfitria2006@gmail.com

2 Sekolah Dasar Paramount, Palembang, Indonesia

E-mail: alee.maxum@gmail.com

3 Universitas Bengkulu, Bengkulu, Indonesia

E-mail: muhammadkristiawan@unib.ac.id
}

Vol.13 (2) August, 2021

Received: June 15, 2021; Received in revised form: July 20, 2021; Accepted: July 21, 2021; Available online: August 8, 2021

This is an open access article under a Creative Commons Attribution-NonCommercial-ShareAlike 4.0 International License 
kehidupan khususnya di dunia pendidikan. Perjalanan trasnformasi disetiap daerah sebagai dampak pandemic Covid-19 tentunya berbeda. Hasil penelitian menunjukkan bahwa perjalanan transformasi pendidikan selama satu tahun pandemi Covid-19 di sekolah Paramount Palembang menunjukkan bahwa semua guru menikmati perubahan ini dan merasakan manfaatnya hasil penelitian ini sangat penting untuk menjadi dasar transformasi sistem pendidikan di sekolah dan pendidikan secara umum. Kebijakan selanjutnya adalah bagaimana transformasi pendidikan dapat dinikmati oleh seluruh peserta didik dengan menggunakan metode pembelajaran yang terintegrasi dalam pembelajaran daring (dalam jaringan) dan luring (luar jaringan).

\section{INTRODUCTION}

Mastery of technological literacy is a necessity. Technology has entered into all spheres and joints of life. Even in its development, it has begun to enter its borders (Susanti, 2013). Not only in fields that are familiar with technology but also in the world of education, teachers must also be aware of and literate in technology or ICT literacy (Muskania, 2017).

This study aims to dissect the impact of Covid -19 on the acceleration of technology transition in the world of education. When the author wrote this article, it had been a year since the pandemic hit the world. In Indonesia, cases of contracting the Covid-19 virus began when a Japanese citizen living in Indonesia contracted the Covid-19 virus when he returned from Malaysia. This is according to the first presidential announcement on March 2, 2020 (Aditya, 2021). No one thought that the first case was the beginning of changes in all fields due to the pandemic outbreak, from the weakening economic impact (Joharudin, 2020) even down to the legal line are also affected by this crisis (Sodik, 2020). Education is the second most affected impact after the economic sector. Especially after the government closed all social activities with the social distancing program, all face-to-face learning activities are entirely closed. It has been a year since students have been using online learning methods, including campus activities at the university (Alia, 2020).

It is considering the conditions that are no longer possible. It is no exception that Elementary Schools and Madrasah Ibtidayyah are carried out remotely both online (within the network) and offline (outside the network). In Indonesia, this policy is also applied to all countries in the world affected by the coronavirus (Carrillo, 2020) (Muskania, 2021). By the circular letter of the Minister of Education and Culture of the Republic of Indonesia Number 4 of 2020 concerning the Implementation of Education Policies in the Emergency Period for the Spread of Corona Virus Disease (Covid-19). This change is not easy because the previously analog learning method has suddenly changed drastically with an online method that feels foreign. The whole education network feels 'forced' to transform distance learning from home (Atsani, 2020). Related to this transformation, both the government and the private sector have issued policies to facilitate access to learning from home. Many media are used in distance learning (Lathipatud Durriyah, 2018). Some applications that can be used in the distance learning process are Whatsapp, Youtube, Telegram, Google classroom, Zoom, Google Meet, Google Form, Quizzis, Khoot, e-learning page, LMS, Video conference, Live chat, Learning House (Platform of Ministry of Education and Culture), the Teacher Sharing Program (the Ministry of Education and Culture Platform), and TVRI for areas with a poor internet connection or no internet connection (Astini, 2020).

The government has issued a Circular Letter of the Minister of Education and Culture Number 9/2018 concerning the Utilization of Learning Houses. From the private sector itself, there are various applications, Zenius, Kahoot, and Ruang Guru. The changes that occur are not without problems. All schools must have the prepared infrastructure, which does not have the same capacity to fulfill it. Infrastructure restrictions and technology adoption are forcing all to learn again because the current situation in the education sector is accelerating the transition to technology-based education (Ultimate, 2020). 
The learning method uses online media which is defined as the transfer of knowledge through online media video communication via text, images, and even software (Basilaia, 2020)which can be done through various methods such as Whatsapp, Instagram, and also applications such as the zoom application media. Various problems arise from not understanding the lesson, not being familiar with technology, and even increasing economic needs such as buying credit. On the other hand, parents still pay fees to school (Sudrajat, 2020).

In terms of teaching, teachers also have problems with technological literacy. Because not all teachers can operate technology and even make learning media well, in other words, teachers must master information technology to support their ability to implement various learning tasks (Primasari, 2020). In this era, all teachers are required to be more creative and collaborative (Fitria, 2020). Besides that, they must also realize that learning must involve psychological, pedagogical, and didactic aspects together (Mulyasa, 2013). This ICT-based learning method also brings new challenges for school principals on how to assess and communicate well. Assessing teacher performance is problematic because it requires good communication standards (Ruslan, 2020), especially with distance learning methods that reduce communication.

It has been a year since Indonesia in particular, and the world is facing the Covid-19 pandemic. Although the transformation of education initially brought difficulties in many sectors and new learning systems, on the other hand, new media have brought fresh air to knowledge which is also new in the field of technology. In this pandemic condition, the principal continues to supervise even though learning is carried out independently online. One of them is using teacher supervision or monitoring through the e-learning supervisor application in schools (Fitria, 2021).

This research was conducted at the Paramount School Palembang, a modern school conducting online learning for one year using zoom media. From the author's observation, Paramount School has implemented a learning method through the zoom application media with the same lesson hours according to a regular class, namely 40 minutes and one hour lesson. The initial use of this learning received many complaints from parents, but it turned out to be acceptable after time because all these learnings were used all over the world. How are the teachers after a year of the pandemic? Does this technological transformation in education also lead them to new skills in the field of teaching technology? How teachers make students comfortable through distance teaching.

The purpose of this study was to find out the changes after one year of the pandemic, namely first, to find out how teachers as teachers transformed from this change, secondly to find out teachers found skills in the use of learning media, and thirdly, to find out the impression and atmosphere of children during a year of the pandemic through distance learning.

\section{METHODS}

This research method uses a qualitative approach. The method used is observation, interviews, and literature study by looking for sources of articles related to the theme that the author took. From the two methods, the authors analyzed so that the materials that could be used in this study were arranged. In addition, it also uses a descriptive content analysis study method. The subjects of this study were the principal and vice-principal of the curriculum section and all teachers at the Paramount Palembang Elementary School who carried out a learning process that was transformed from conventional learning to distance learning, twenty-fourth, fifth, and sixth graders were the subjects of the implementation of this learning transformation, which aims to provide an overview of the contents of certain information or text (Munirah, 2015).

\section{FINDINGS AND DISCUSSION}

In March, the author researched the impact of the COVID-19 pandemic on educational transformation at the Paramount Palembang school through surveys, field observations, and interviews with school principals. The author gets information about the learning method used, the 
impact of using teaching technology on teachers, the effectiveness of its use, and the use of technological facilities due to the pandemic and its post-pandemic application.

The learning process with a remote, online, or offline system for students at the elementary school level is expected by students and parents not to give assignments continuously. It would be better if the learning process is filled with the delivery of material by the teacher via video so that students can repeat it. In addition, in the lower grades, the distance learning process is fully accompanied by parents. Even the parents or guardians of the students are more involved in completing assignments. This has a negative impact on the development of students because it indirectly teaches students to be dishonest. At the same time, primary education is the main foundation for instilling character values such as honesty to grow with solid character roots.

At Paramount Palembang school, the use of IT technology in teaching is nothing new for teachers. So when PJJ (Distance Learning) applies teaching technology using information technology, Paramount teachers are ready. This is evident from the survey that the author distributed via a google form, asking whether they are not comfortable using technology? As many as $\mathbf{9 1 . 7 \%}$ said no, it means the majority are familiar with teaching technology. The rest answered yes and maybe.

Perceived changes while using distance learning: 50\% positive, $16.7 \%$ negative, and $33.3 \%$ very favorable. The method used during PJJ was $50 \%$ video, $20.8 \%$ used all methods, $8.3 \%$ combined with all methods such as animation, video, pictures, and discussions. However, the distance learning system is a new system during the pandemic and will have both positive and negative impacts. The author questions whether students feel a positive impact with the methods they provide? As much as $50 \%$ feel enough, do not know $8.3 \%$ and $41.7 \%$ feel. Teachers also felt the positive impact of learning new things about technology during distance learning, with a percentage of $91.7 \%$ and $8.3 \%$ said sometimes.

Table 1. Transformation of learning at Elementary School Paramount Palembang

\begin{tabular}{lll}
\hline Learning process & Percentage & Category \\
\hline Distance learning (Using & $50 \%$ & positive \\
\cline { 2 - 3 } $\begin{array}{l}\text { Videos, animations, and } \\
\text { pictures) }\end{array}$ & $16.7 \%$ & negative \\
\cline { 2 - 3 } & $33.3 \%$ & very positive \\
\hline
\end{tabular}

Based on table 1 above, it can be concluded that the transformation of learning brings positive changes, and the learning process at Elementary School Paramount Palembang is very dynamic. Other positive impacts that are felt include teachers learning with the latest applications (29.2\%), learning methods (33.3\%), and the rest feel more creative (25\%). Minister Nadim Makarim that the learning system with the Covid period system will still be used even though the pandemic is over(Bramasta, 2020); directly proportional to this, the enthusiasm of Paramount teachers after implementing distance learning is relatively high. This is like the author asking whether, after distance learning, methods like this are quite effective and need to be continued after the pandemic is over? $50 \%$ said it was necessary, maybe (20.8\%), and not necessary (12.5\%), and $16.7 \%$ said it was very necessary.

Table 2. Positive Impact of Learning Transformation at Elementary School Paramount Palembang

\begin{tabular}{lll}
\hline Learning process & Percentage & Category \\
\hline Does distance learning need to & $50 \%$ & Need \\
\cline { 2 - 3 } be continued in the future & $20.8 \%$ & Maybe \\
\cline { 2 - 3 } learning process? & $12,5 \%$ & No need \\
\cline { 2 - 3 } & $16.7 \%$ & It is necessary \\
\hline
\end{tabular}


Based on table 2 above, the method applied by Paramount Palembang Elementary School with full online also received a positive response. The children liked the method provided by the school, namely 50\% said they liked it very much, $41.7 \%$ said enough, and the rest said maybe yes or no.

Of the various positive impacts felt, with a high percentage of teachers still wanting to use technology in teaching, 91.7\% answered that they still used it, and 8.3\% answered that it was possible. Furthermore, even more proud of it, the teachers will continue to develop skills in technology after experiencing the distance learning experience, as many as $95.8 \%$ answered that they would continue to develop it, and the rest answered maybe.

COVID-19 has significantly impacted online education as schools and universities were required to shift to $100 \%$ online modality almost overnight. For the information management field, this presents an opportunity to research best practices in pedagogies, technologies, and assessments of information system discipline to maintain the level of engagement, personal connection, and presence expected within a face-to-face classroom environment. All of which are required while maintaining academic integrity. This is critical to maintaining the supply of qualified professionals in the information system-related field. The expert perspectives offer timely insight into the range of topics, identifying key issues and recommendations for theory and practice (Davison, 2020).

Paramount Palembang Elementary School has the power to carry out learning transformations, especially during the current COVID-19 pandemic, which is the trigger for the transformation.

\section{CONCLUSION}

From research conducted at the Paramount school in Palembang, it has given very positive results. It can be seen from the data that teachers have enjoyed the application of information technology applications in distance teaching. This is supported by the skills that have been applied in previous Paramount schools so that the implementation process goes without a hitch. Although on the way, there are difficulties to do creative understanding to parents. Furthermore, in various methods, teachers also find new skills as teaching methods such as animation, teaching video recordings through video editing, and online discussions. From the various transformation processes above, the impressions made by both teachers and children affected by this transformation process also feel a positive impact because the majority also like the given system. The reality of the transformation of educational technology in Indonesia provides such an important role that it requires teachers and students to have a qualified ICT Literacy to implement the distance learning process as expected. Many obstacles were found at Elementary School Paramount Palembang in the online learning process, especially in the formation of students' character, especially elementary school students who cannot be replaced by technology.

\section{REFERENCES}

Aditya, N. R. (2021, 3 2). Kompas.com. (K. Erdianto, Editor) Retrieved Maret 11, 2021, from nasional.kompas.com: https://nasional.kompas.com/read/2021/03/02/05300091/satutahun-pandemi-covid-19-di-indonesia-kilas-balik-kisah-pasien-01-dan-02?page=all

Alia, S. R. (2020). Budaya Lembaga Pendidikan sebagai Pilar Utama Melawan Degradasi Moral. Khazanah Pendidikan Islam, 2(2), 84-89.

Astini, N. K. S. (2020). Pemanfaatan teknologi informasi dalam pembelajaran tingkat sekolah dasar pada masa pandemi covid-19. Jurnal Lembaga Penjaminan Mutu STKIP Agama Hindu Amlapura, 11(2), 13-25.

Atsani, L. G. (2020). Transformasi Media Pembelajaran Pada Masa Pandemi Covid-19. Al Hikmah, Jurnal Studi islam, 1(1), 82.

Barbara Bruschi, Marina Marchisio, Matteo Sacchet. 2021. Online Teaching in Higher Education with the Support of Start@Unito During Covid-19 Pandemic. Bridges and Mediation in Higher Distance Education, pages 187-198.

Bramasta, D. B. (2020, 7 3). www.kompas.com. (I. D. Wedhaswary, Editor) Retrieved from www.kompas.com/tren:https://www.kompas.com/tren/read/2020/o7/03/155830065/me nteri-nadiem-wacanakan-belajar-jarak-jauh-permanen-setelah-pandemi-covid?page=all 
Carrillo, C. \&. (2020). Covid-19 and teacher education: a literature review of online teaching and learning practice. European Journal of Teacher Education, 43 (4), 466-487. Retrieved from https://doi.org/10.1080/02619768.2020.1821184

Davis, I. (2011). Instructional Technique. New York: McGraw Hill Book Company.

Davison, R. M. (2020). The transformative potential of disruptions: A viewpoint. International Journal of Information Management, 102149. https://doi.org/10.1016/j. ijinfomgt.2020.102149.

Dewi, W. A. F. (2020). Dampak COVID-19 terhadap Implementasi Pembelajaran Daring di Sekolah Dasar. Edukatif : Jurnal Ilmu Pendidikan, 2(1), 55-61. https://doi.org/10.31004/edukatif.v2i1.89

Fitria, H. S. (2020). Role of Teachers in Digital Instructional Era. Journal of Social Work and Science Education, 1(1), 72.

Fitria, H, dkk (2021). The Effectiveness of Internet-Based Supervision on The Covid 19 Pandemic Situation. Tadbir: Jurnal Studi Manajemen Pendidikan, 1(5),19-32. http://dx.doi.org/10.29240/jsmp.v5i1.2174

Joharudin, A. S. (2020). Panic Syndrom Covid-19: Penekanan Terhadap Kebijakan Yang diberikan. Journal Perspektif, 4, 44-53.

Kumar, K. S., Fathurrochman, I., Mahendraprabu, M., Ramnath, R., \& Kumar, N. S. (2019). Usage and Performance of Open Educational Resources among State Universities of Tamil Nadu. International Journal of Management and Humanities (IJMH), 5(10) 1-8. https://www.ijmh.org/wp-content/uploads/papers/v5i10/I1311055921.pdf.

Lathipatud Durriyah, T. \&. (2018). Digital Literacy With EFL Student Teachers: Exploring Indonesian Student Teachers' Initial Perception About Integrating Digital Technologies Into a Teaching Unit. Education and literacy studies. 6(3).

Murfi, A., Fathurrochman, I., Atika, A., \& Jannana, N. S. (2020). Kepemimpinan sekolah dalam situasi krisis Covid-19 di Indonesia. MANAGERIA: Jurnal Manajemen Pendidikan Islam, 5(1), 119-136. https://doi.org/10.14421/manageria.2020.51-07

Muskania, Z. M. (2021). Realoita Transformasi Pendidikan di Sekolah Dasar Sekolah Selama Pandemi Covid-19. Jurnal Pendidikan dasar Nusantara, 6(2).

Pamungkas, S. (2020). Transformasi Dunia Pendidikan di sekolah Dasar Dalam Masa Pandemi Covid-19. Journah Review Pendidikan Dasar: Jurnal Kajian Pendidikan dan Hasil penelitian, 6(3).

Primasari, D. A. (2020). Developing Instructional Media of Curriculum 2013 Based on Information and Communication Technology. Edication Journal, 3, 24-34.

Ricka Muskania, Zulela MS. (2021) Realita Transformasi Digital Pendidikan di Sekolah Dasar Selama Pandemi Covid-19. JURNAL PENDIDIKAN DASAR NUSANTARA 6:2, pages 155165. https://doi.org/10.29407/jpdn.v6i2.15298

Ruslan, B. L. (2020). The Influence of Principal's Situational Leadership and Teacher's Professionalism on Teacher's Performance. International Journal of Progressive Sciences and Technologies (IJPSAT), 2O(1), 138.

Ruth Zuzovsky, Smadar Donitsa-Schmidt. (2020) Professionalization and Professionalism of Teaching and Teachers in Israel. Parezja. Czasopismo Forum Młodych Pedagogów przy Komitecie Nauk Pedagogicznych PAN:1(13), pages 55-62. https://repozytorium.uwb.edu.pl/jspui/handle/11320/10230

Smadar Donitsa-Schmidt \& Rony Ramot (2020) Opportunities and challenges: teacher education in Israel in the Covid-19 pandemic, Journal of Education for Teaching, 46:4, 586-595, DOI: https://doi.org/10.1080/02607476.2020.1799708

Sodik, A. A. (2020). JUSTICIABELEN: Penegakan Hukum di Institusi Pengadilan dalam menghadapi Pandemi Covid-19. Khasanah Hukum, 2(2), 56-64.

Susanti, R. (2013). Teknologi Pendidikan Dan Peranannya Dalam Pembelajaran Jarak Jauh. Jurnal Teknologi Pendidikan. Program Studi Teknologi Pendidikan., 2.

Tesi Muskania, R. \&. (2017). Pengembangan Perangkat Pembelajaran Project-Based Learning Untuk Membekali Foundational Knowledge Dan Meningkatkan scientific literacy. Jurnal Cakrawala Pendidikan, 36, 34-43. 